\title{
シリコーン樹脂の構造制御と物性発現
}

\author{
上 原 宏 樹 ${ }^{* 1} \cdot$ 山延 健 ${ }^{1}$ 秋 山 映 ${ }^{2}$
}

\section{Structural Control and Property Development of Silicone Polymers}

Hiroki UEHARA $^{* 1}$, Takeshi YAMANOBE ${ }^{1}$ and Eiichi AKIYAMA ${ }^{2}\left({ }^{* 1}\right.$ Division of Molecular Science, Faculty of Science and Technology, Gunma University, 1-5-1 Tenjin-cho, Kiryu, Gunma 376-8515, Japan, ${ }^{2}$ Sagami Chemical Research Institute, 2743-1 Hayakawa, Ayase, Kanagawa 252-1193, Japan)

Typical silicones, including poly(dimethyl siloxane)(PDMS), are amorphous, but poly(tetramethyl- $p$-silphenylenesiloxane)(PTMPS) containing phenyl rings in the main chain is crystalline. A combination of in-situ X-ray and NMR measurements during heating of PTMPS indicates that the molecular motion of the phenyl rings exhibits remarkable anisotropy even in the molten state, suggesting rigidity of the PTMPS molecules. Therefore, a melt-drawing technique could be successfully applied to PTMPS. The obtained melt-drawn PTMPS membrane is transparent but exhibits an excellent tensile modulus and strength of $1.7 \mathrm{GPa}$ and $20 \mathrm{MPa}$, which are enough for various industrial applications. Similar introduction of phenyl rings in the main chain is also effective for property development of silicone elastomer. Blend films of PTMPS and silicone elastomer exhibits the characteristic phase separation, depending on the blending compositions. Such blend films give the remarkably higher tensile strength than the original silicone elastomer, due to the crystalline component.

(Received on April 4, 2017)

Key Words : Silicone, Crystalline, PTMPS, In-Situ Measurements, Drawing, Elastomer, Blend, Strength

\section{1. は じ め に}

シリコーンは，シロキサン結合の繰り返しから構成さ れ, 耐熱・耐寒性, 化学安定性, 生体適合性など, 石油由 来の炭化水素系ポリマーとは異なった特徵を示す．このよ うな特性のため, 自動車部材や医療材料として利用されて いる，さらに，流動性が高く柔軟であるため，加工性に優 れており,コーティング剤や複製品の型などにも用いられ ている．また，架橋反応を利用することで接着剤としても 用いられる.

その中でも，ポリジメチルシロキサン（PDMS）は幅広 い用途で用いられているシリコーンであり，その架橋体は シリコーン・エラストマーとして利用されている.この架 橋反応には，一般に白金錯体等の金属触媒が用いられてい るが，医用材料などへの応用を考えると，金属触媒フリー で架橋反応が進行することが望ましい.ここで，ハイドロ
ジェンシロキサンを多分岐型に改良した Hyper-Branched Crosslinker（HBC）は多数の分岐末端にヒドロシリル基 を有する反応性シリコーンであり（図1（a），金属触媒 を用いずに架橋反応を進行させることができる，このよう な架橋反応の進展は, 昇温過程で「その場 (in-situ)」 NMR 測定を行うことで追跡することが可能である ${ }^{11}$.

一方, 同じシリコーンでも, 結晶性のものも存在する. ポリテトラメチル-p-シルフェニレンシロキサン (PTMPS) は主鎖に剛直なベンゼン環を有するシリコーンである (図1（b)).PTMPSはすでに1960年代に合成が報告され ており ${ }^{2)}$, 前述のPDMS等とは異なり, 結晶性を示すこと が知られている。このPTMPSについて, 我々は, 融点以 上であってもフェニレン基の運動性は軸対象な異方性を持 つことを見出した ${ }^{3)}$. これを利用して, 融点以上で延伸を 行うと, 分子鎖が配向することで高い破断強度を持つフィ ルムを調製することができる ${ }^{4)}$. 
(a)

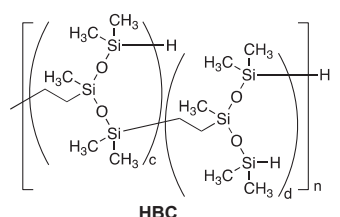

(c)

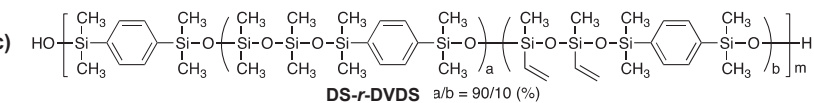

図 1 本研究で対象とした特殊構造シリコーン

このようなフェニレン基の導入は, 非晶性のシリコー ン・エラストマーの改質にも有効である。我々は, PDMS 主鎖の一部にフェニレン基を導入した新規シリコーン （DS- $r$-DVDS）を合成し（図 1 (c)），これを上記の HBC と熱架橋させたシリコーン・エラストマーを調製した，得 られた架橋フィルムの引っ張り強度は, 市販シリコーン・ エラストマーの約 3 倍に達しており ${ }^{5)}$ ，フェニレン基の導 入が極めて効果的であることを表している.

ここで，市販のシリコーン・エラストマーは単体で用い られることは少なく, 強度の補強や機能性の付与のために カーボンブラック, シリカやガラスファイバーなどの無機 フィラーが添加されている ${ }^{6-9)}$. しかし，フィラーとシリ コーン・エラストマー界面で剥離が起きるため, エラスト マーの重要な特性である伸度がエラストマー単体より低下 する ${ }^{10,11)}$.これを改善するために, フィラーの表面の改質 等が行われているが, フィラーの添加に伴い, シリコー ン・エラストマーの柔軟性や勒性は失われてしまう ${ }^{11,12)}$.

そこで，シリコーン・エラストマー成分と親和性を有す ると考えられるPTMPSをフィラーの代わりに添加すれ ば，破断強度に優れた新規エラストマーが創製できると考 えた，具体的には，PTMPSと架橋前の反応性シリコーン 原料が両方とも同一溶媒に溶解することを利用して，これ らを溶液状態でブレンド後, 架橋と溶媒揮発を同時進行さ せることで, 架橋シリコーン特有の柔軟性を維持しつつ, かつ高強度を有するエラストマー材料の創製を試みた。そ の結果, 特異な引っ張り特性を有する高強度エラストマー が得られている ${ }^{13)}$.

本稿では，これら我々の研究グループがこれまで行って きた一連のシリコーン樹脂の構造制御と物性発現に関する 研究例を紹介する.

\section{In-situ NMR計測による架橋反応の追跡とエラストマー の物性 ${ }^{1)}$}

フェニレン基を主鎖骨格に導入した新規シリコーン （DS- $r$-DVDS） と多分岐型架橋剂（HBC）を重量比 $1: 1$ で混合し，これを昇温した際のin-situパルスNMR測定を 行った. 図 2 は, 各測定温度で得られた緩和プロファイル （FID）を重ね書きしたものである。金属錯体触媒を用い
ていないため, ノイズのないプロファイルが得られてい る. まず, $40{ }^{\circ} \mathrm{C} \sim 100{ }^{\circ} \mathrm{C}$ ま゙は温度が上昇するに従って, FID曲線の傾きが徐々に緩やかになっていることがわか る. 一方, $120{ }^{\circ} \mathrm{C} \sim 180{ }^{\circ} \mathrm{C}$ では緩和時間の短い成分が出現 するため, FID曲線が下がって見える。この緩和時間の短 い成分は，運動性が制限されている成分，すなわち，架橋 成分に対応する。なお，この昇温測定の後， NMR 試料管 を室温に冷却したところ，得られた試料はゴム状であり， 架橋反応が起こっていることが確認できた。

そこで，これらの熱架橋反応で起こる構造変化を定量的 に議論するために，FID曲線の成分解析を行った。一般 に, パルス NMRの FID 曲線は次のExponential 関数（式 (1)）で表せることが知られている ${ }^{14)}$.

$$
I(t)=I_{0} \exp \left(\frac{-t}{T_{2}}\right)
$$

ここで， $t$ は時間， $I(t)$ は時間 $t$ における信号強度， $T_{2}$ はスピンースピン緩和時間である。図 2 の FID曲線は， 2 成分あるいは 3 成分でフィッティングすることができた. 図 3 は, これら各成分の緩和時間 $T_{2}(\mathrm{a})$ と成分比（b) を 温度に対してプロットした結果である。ここで, 緩和時間 $T_{2}$ は, 值が小さいほど分子運動性が低く硬いことを示し ており，逆に $T_{2}$ が長いほど分子運動性が高く柔らかいこ とを意味している。まず, $T_{2}$ の結果を見ると，室温では $T_{2}$ が長く柔らかい Mobile 成分と $T_{2}$ が中程度の Intermediate成分の 2 づ存在しており, 熱架橋温度である $110{ }^{\circ} \mathrm{C}$ 以上になると $T_{2}$ が短く硬い Rigid成分が出現する。この Rigid成分は前述したように架橋成分である. $110{ }^{\circ} \mathrm{C}$ 以上 になると, Mobile成分およびIntermediate成分の $T_{2}$ が 徐々に減少している。これは, 架橋反応の進行に伴い, そ の周りの成分の運動性も制限を受けるためであると推察さ れる。一方, 図 3 （b）の成分比の推移を見ると, 室温で は Mobile 成分と Intermediate成分が50\%ずつで存在し,

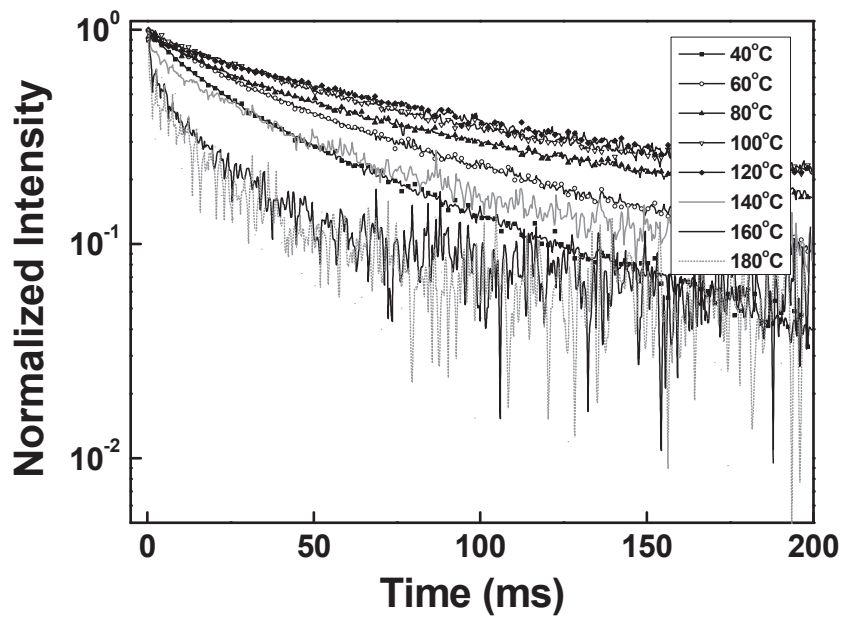

図2 DS- $r$-DVDS / HBCブレンドの昇温過程で記録したFID 曲線. 
$110{ }^{\circ} \mathrm{C}$ 付近から Mobile成分が急激に減少しており, $140{ }^{\circ} \mathrm{C}$ 付近から Intermediate成分が徐々に減少していることが わかる．またそれと同時に架橋成分である Rigid成分が 60 \%近くにまで達していることがわかった。 ここで, DS- $r$ DVDS 単体およびHBC 単体を昇温して得られた結果から， Intermediate成分はDS- $r$-DVDSに，Mobile成分はHBCに 帰属することができた。

これらの結果を基にDS- $r$-DVDS / HBCブレンドの熱架 橋挙動をモデル化すると，図4のようになる。架橋前の状 態では，Mobile成分に相当する HBC と Intermediate成分 に相当するDS- $r$ DVDSが $50 \%$ ずつ存在しているが，これ を昇温していくと，110 ${ }^{\circ} \mathrm{C}$ 以上で架橋成分である Rigid 成 分が出現するとともにMobile成分量は急激に減少し，そ の後, Intermediate成分量も $140{ }^{\circ} \mathrm{C}$ 付近から徐々に減少し ている. 従って, DS- $r$-DVDS / HBCブレンドでは, 最初 に $\mathrm{HBC}$ 同士での架橋反応が起こり，その後，分子運動性 が向上したDS- $r$-DVDS と HBCが架橋反応を起こすと考え られる。

これら熱架橋によって得られた新規シリコーン・エラス トマーの力学物性を室温での引張り試験により評価した (図5).これまでと同じDS- $r$-DVDS : HBC = 1：1の重量
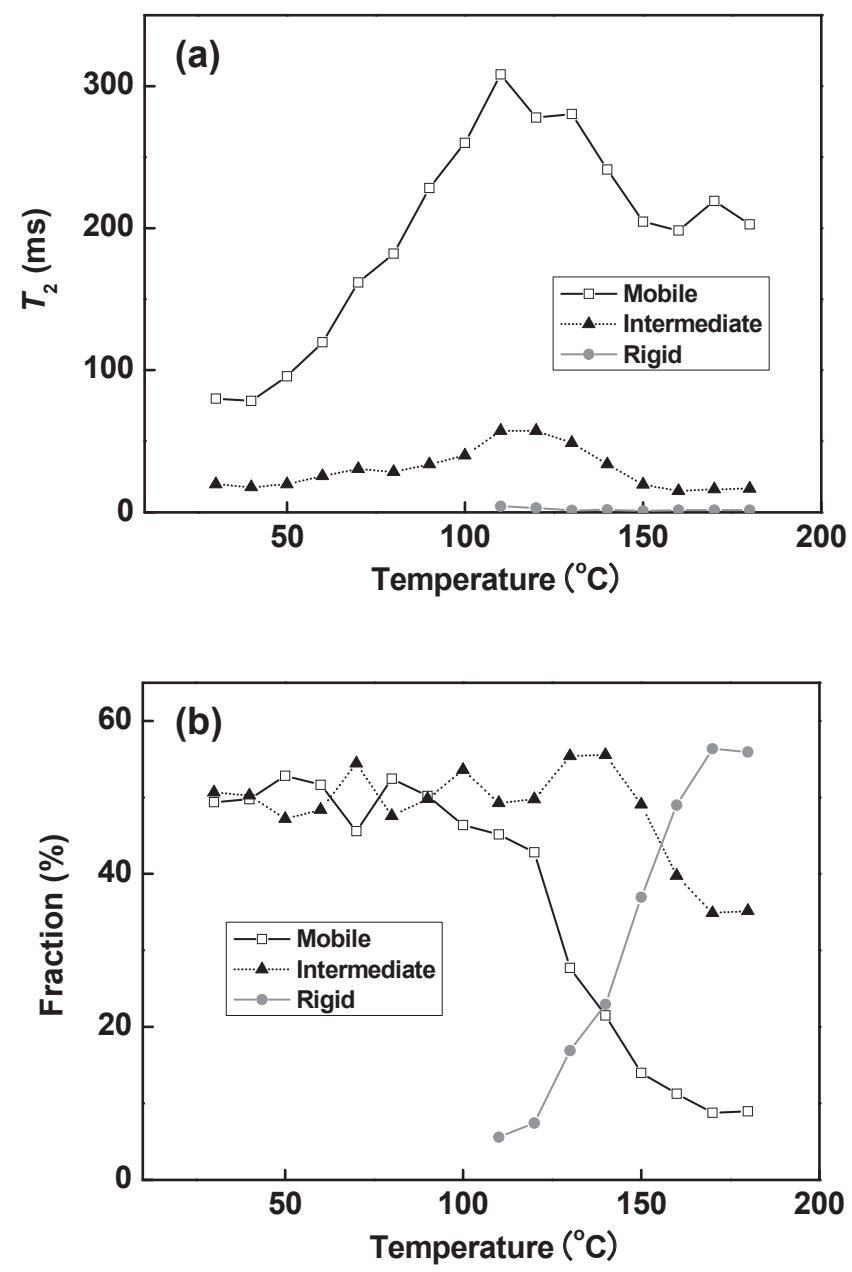

図3 DS- $r$-DVDS / HBCブレンドの各温度で測定したFIDから見積 もった各成分の $T_{2}$ 変化（a）と比率変化（b）。 比で調製した試料（a）の他に, DS- $r$-DVDSに含まれるビ ニル基量と $\mathrm{HBC}$ に含まれるヒドロシリル基量が $1: 1$ とな るようにブレンドした試料（b)，比較として，白金錯体 触媒を用いて市販PDMSを架橋した試料（c）を準備した。 本研究の新規シリコーンでは, 重量比 1：1（a）では強度 に劣るものの, 反応系内のビニル基量とヒドロシリル基量 を適合させることにより，（b）では引張り弾性率 $2 \mathrm{MPa}$, 破断強度 $0.35 \mathrm{MPa}$ が得られた。これらの值は, 市販シリ コーン（c）の約 20 倍および 3 倍に相当する。このことは, DS- $r$-DVDSの剛直性を反映している.
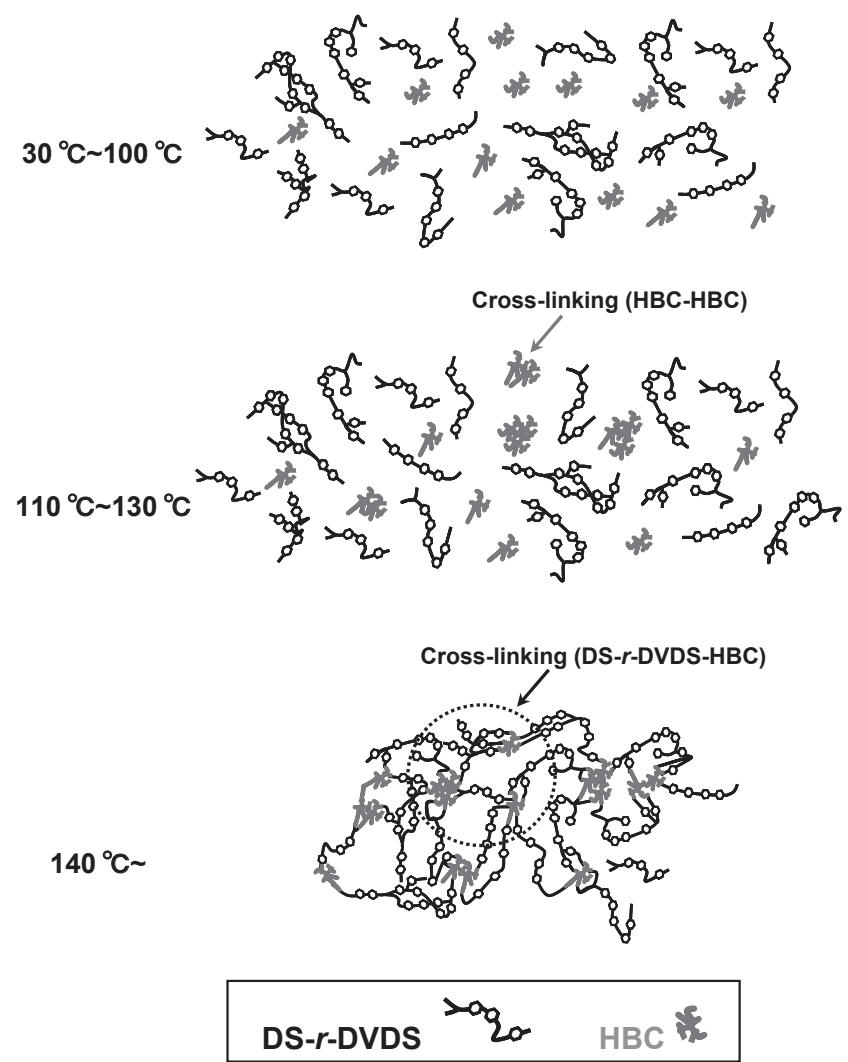

図4 DS- $r$-DVDS / HBCブレンドの熱架橋に伴う分子構造変化モデル.

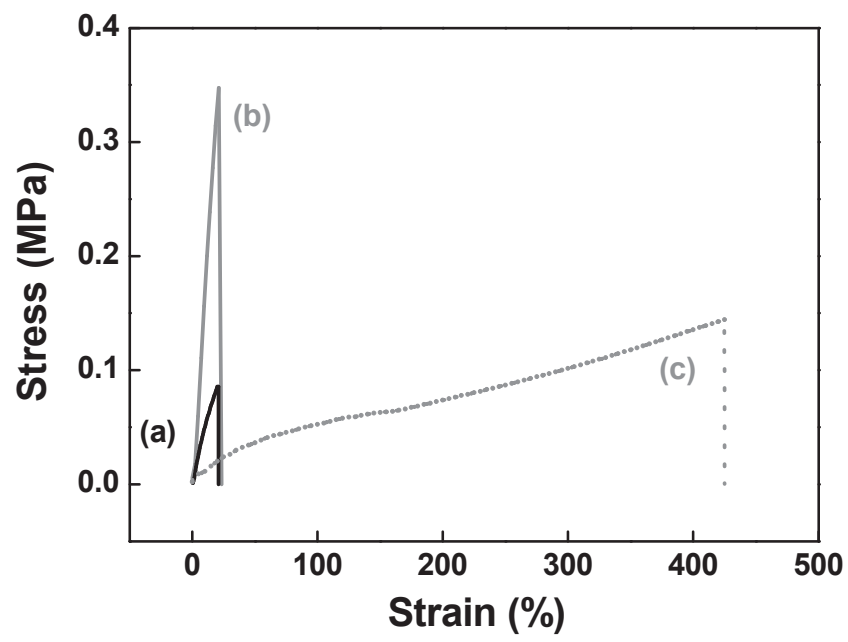

図 5 得られたシリコーン・エラストマーの応力・歪み曲線（室温）. (a) DS- $r$-DVDS : $\mathrm{HBC}=1: 1$ ，(b）ビニル基：ヒドロシリル 基量 $=1: 1$ および (c) 市販シリコーン（白金錯体触媒）. 


\section{PTMPSの昇温過程における in-situ 計測 ${ }^{3)}$}

結晶性シリコーンであるPTMPSを合成し，これを溶液 キャストしてフィルムを調製した。これを昇温した際の相 転移挙動をin-situ X 線㧍よびNMR測定により追跡した. 図6（a）に，PTMPSフィルムの80〜180 으打ける in-situ広角X線回折（WAXD）像から切り出したライン プロファイルを重ね書きしたものを示した。なお，青から 赤になるに従い回折強度が高くなることを表している. $130{ }^{\circ} \mathrm{C}$ まではPTMPS結晶に由来する反射が明確に観察さ れているが，140 ${ }^{\circ} \mathrm{C}$ 付近で消失し，非晶ハローのみとなっ ていることがわかる。この温度はDSC 測定における融解 ピーク温度（図6の点線）と一致している。ここで，ポリ エチレン等の通常の高分子結晶では昇温による格子膨張に よってピーク位置が低角側にシフトするが ${ }^{15)}$, PTMPSは 融解に至るまで反射ピーク位置がほとんど変化しておら
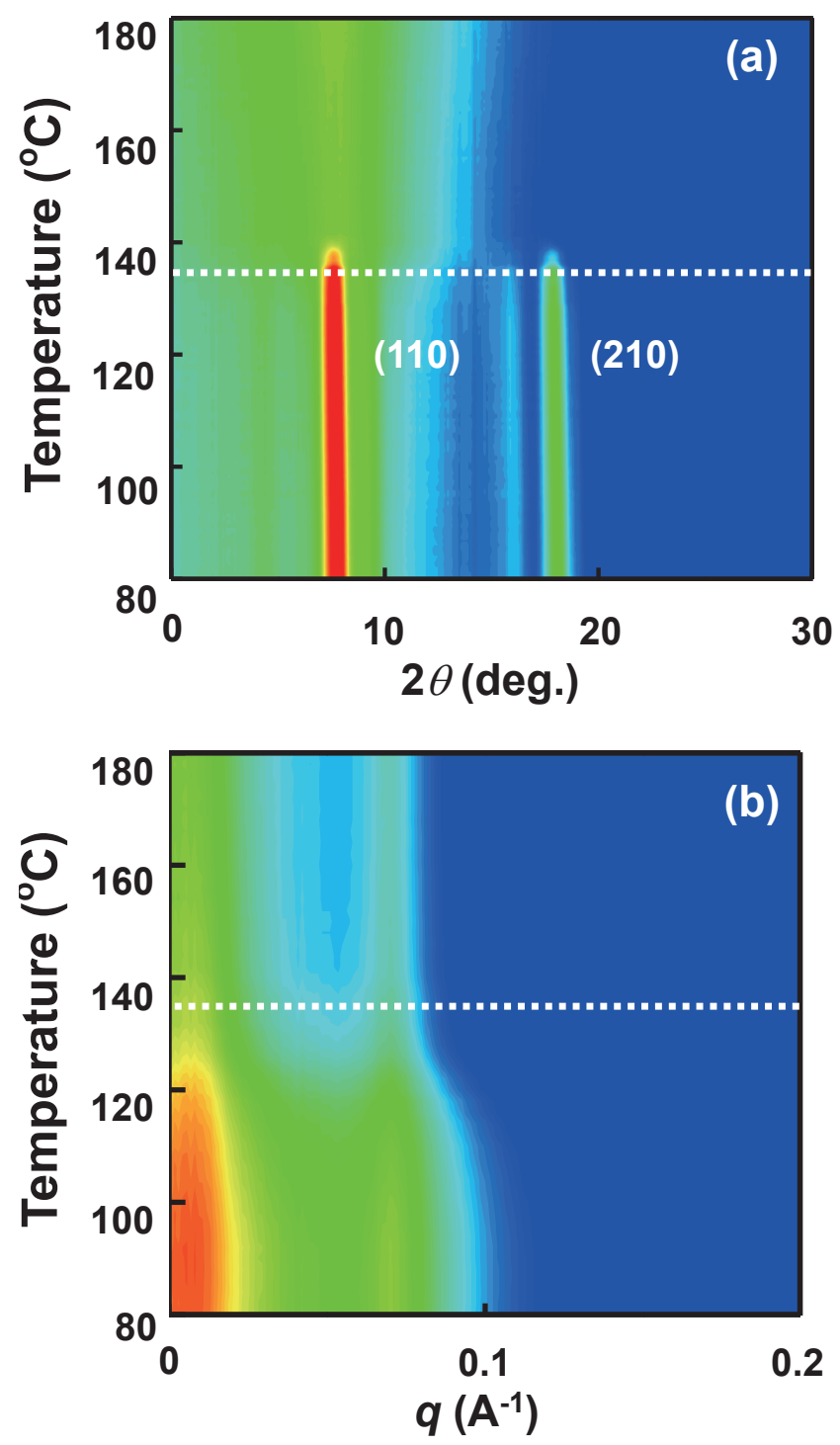

四6 PTMPSフィルムの昇温過程で記録したin-situ WAXD像（a） およびSAXS像（b）から切り出したライン・プロフィルの重 ね書き。点線は, DSC 融解ピーク温度.
ず，結晶内の分子鎖パッキングが強固であることを示唆し ている.

In-situ小角 X 線散乱（SAXS）像についても, 同様にラ インプロファイルを切り出して重ね書きした（図6（b)). 散乱べクトル $q=0.08 \AA^{-1}$ 付近に長周期ピークが観察され ていることから，ラメラ構造を形成していることがわか る。このピークの強度は $120{ }^{\circ} \mathrm{C}$ から次第に減少するが, 融 点である $140{ }^{\circ} \mathrm{C}$ 超えても依然として残存している.この ことは, 溶融状態であってもラメラ構造の長周期性がある 程度維持されていることを示している。

次に, PTMPSの融解挙動をコンホメーションや分子運 動の観点から検討するために，溶液キャストフィルムの昇 温過程における in-situ固体高分解能 ${ }^{13} \mathrm{C}-\mathrm{NMR}$ 測定を行っ た。まず，室温で測定したCPMASスペクトルを図7に示 した.フェニレン基のピークは，141 ppm（1）と 132 ppm（2）に出現しているが, スピニングサイドバンド (SSB) が多く現れていることから異方性を有しているこ とがわかる. 一方，メチル基のピークは $1 \sim 3 \mathrm{ppm}$ (3) に現れている．これらのピークの面積を温度に対してプロ ットしたところ（図 8), $130{ }^{\circ} \mathrm{C}$ 以上でメチル基とフェニレ ン基の両方のピーク強度が減少し始めていた。 この温度で はメチル基の化学シフトは高磁場側にシフトしていたの で，メチル基が結合した Siのまわりの結合の回転運動が 活性化していると言える。 これに対して，フェニレン基の 化学シフトはほとんど変化が認められなかった。したがっ て，フェニレン基のピーク強度の減少はフェニレン基自体 の回転運動によるものではなく, $\mathrm{Si}$ のまわりの結合の回転 運動によってフェニレン基間の相互作用が減少することに 起因すると推測される。そこで，フェニレン基に注目して 化学シフト異方性（CAS）を評価したところ， $130{ }^{\circ} \mathrm{C}$ 以上 で急激に減少し，異方性が平均化されることがわかった

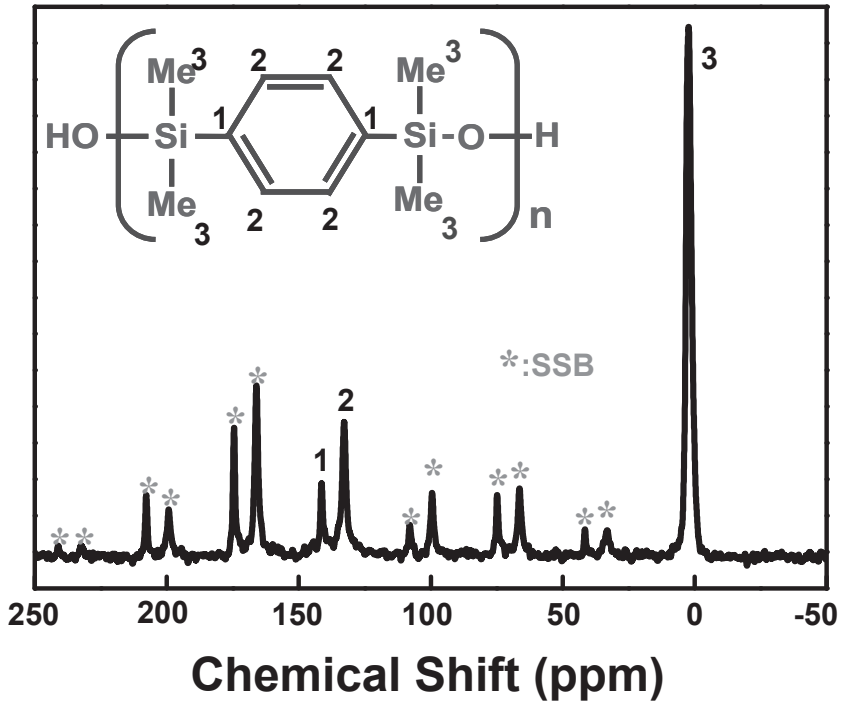

図7＼cjkstart室温で測定したPTMPSフィルムのCPMASスペクトル。 
(図9)。しかしながら，完全にゼロにはなっておらず，融 点以上であっても，フェニレン基が分子鎖軸に対称な滑り 運動をしていることを示唆している。

これらの結果から, PTMPS 結晶の融解は $140{ }^{\circ} \mathrm{C}$ 付近で 起こるが, $120{ }^{\circ} \mathrm{C}$ 付近からフェニレン基の間の滑り運動が 始まり，これによって元々あったラメラの長周期性が融解 後もある程度保持されると考えられる。このような溶融状 態におけるPTMPS分子鎖の構造異方性を利用すれば，効 果的な分子配向の導入が可能であると期待される.

\section{PTMPS フィルムの溶融延伸 ${ }^{4)}$}

そこで，溶融状態であっても分子異方性を有するという PTMPSの特徵を利用するアプローチとして，配向処理を 施すことで分子鎖の配向化を試みた。ささらに，得られた配 向フィルムの力学物性を引張試験によって評価し, これら を無配向フィルムと比較して, 分子配向がPTMPS フィル ムの諸物性に与える影響について考察した.

前項と同様に, PTMPSをp-キシレンに沸点近傍で溶解

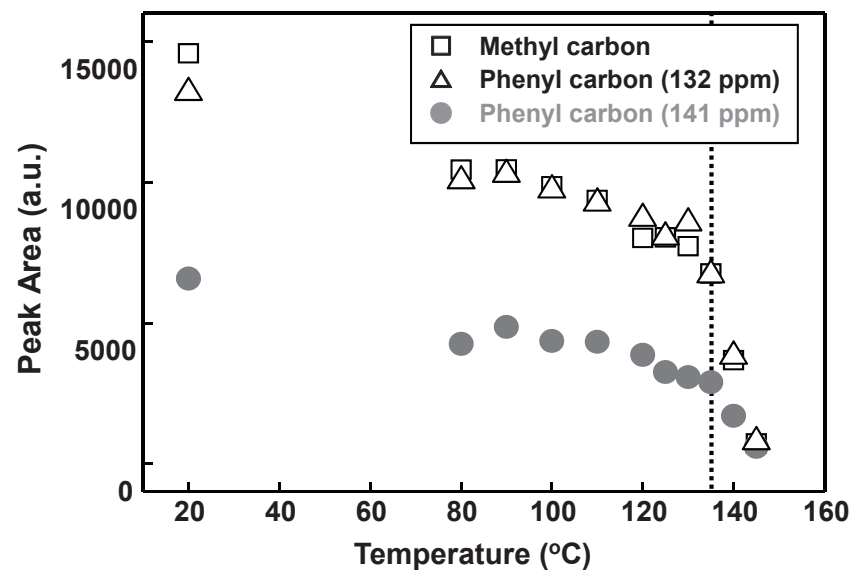

図8 CPMASスペクトルから見積もったメチル炭素抢よびカルボニ ル炭素のピーク強度の昇温に伴う変化

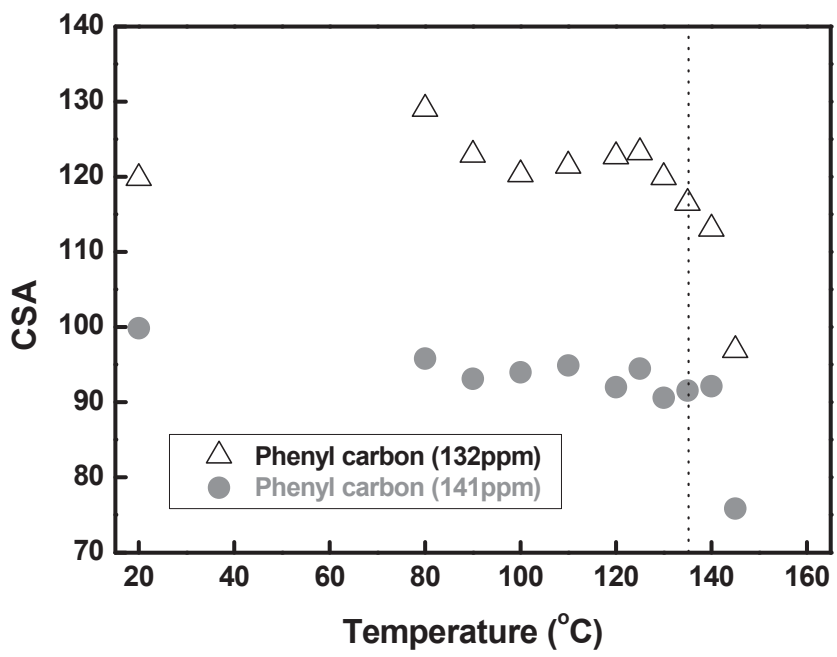

図9 CPMASスペクトルから見積もった化学シフト異方性（CAS） の昇温に伴う変化.
し，これをキャストしてフィルムを成形した。これを融点 近傍の 120 〜 $160{ }^{\circ} \mathrm{C}$ で引張り延伸したが, 延伸開始ととも に試料が破断してしまい，延伸フィルムは得られなかっ た。そこで, これらの温度でロール延伸を行ったところ, すべての延伸温度でフィルム形状を維持していた．特に， 融点以上でのロール延伸により得られたフィルムは透明で あった。

図 10 に各温度でロール延伸したフィルムのWAXD像お よびSAXS像を比較した。なお，ロール延伸時のローラー の回転方向を延伸方向とし，これが上下方向になるように

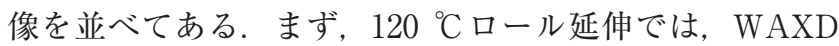
像における各結晶反射がリング状であり，分子鎖の配向は 認められないが, 延伸温度の上昇とともにアーク状に変化

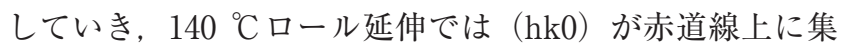
中していることがわかる. 図11（a）は，この $140{ }^{\circ} \mathrm{C}$ 延伸 フィルムのWAXD像を拡大し, 面指数とともに示したも のである. PTMPS結晶は, $a=b=0.902 \mathrm{~nm}, c=1.543$ $\mathrm{nm}$ の正方晶系をとることが知られている ${ }^{17,18)}$. 特に強い 反射強度を示す（110）は，分子鎖パッキングの配列方向 であり，フェニル環が互いに斜めになるように最密パッキ ングしている面である.この面が赤道線上に強く現れてい ることから，分子鎖軸はロール延伸方向に平行に配列して いることがわかる。 また, PTMPS結晶の分子鎖軸方向は c軸であるので，これと垂直に配列した（004）反射が子 午線上に集中していることも，このことを支持している. 一方, SAXS像に赤道線方向に強いストリークが出現して いる。このような赤道線ストリークはポリエチレンを溶融 延伸した際にも認められ ${ }^{18)}$ ，伸び切り鎖結晶の生成に由来 するものと帰属されている。

さらに延伸温度が高くなると, WAXD像のアーク状反 射の強度は次第に減少し, $160{ }^{\circ} \mathrm{C}$ でロール延伸したフィル ムでは，無配向な結晶リングと非晶ハローが観察されてい

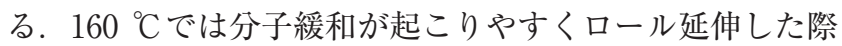
の変形が保持されずに室温に急冷された結果であると推測

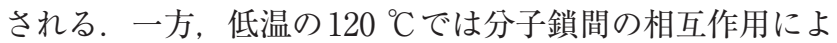
る束縛が強く, ロール延伸を施しても分子配向化はあまり

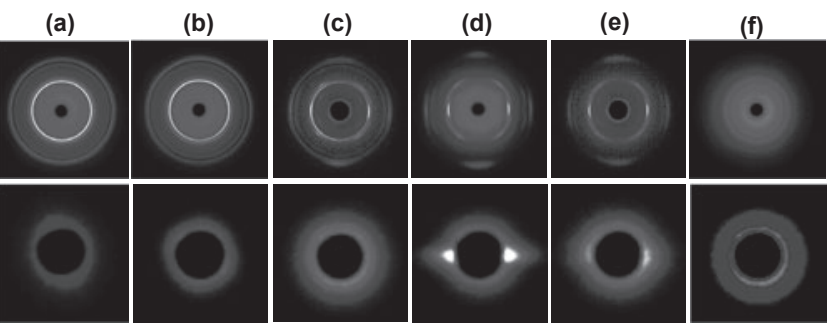

図10 各温度でロール延伸したPTMPSフィルムのWAXD像（上段） とSAXS 像（下段）、ロール延伸方向は縦方向。（a）未延伸フ イルム, (b) $120{ }^{\circ} \mathrm{C}$, (c) $130{ }^{\circ} \mathrm{C}$, (d) $140{ }^{\circ} \mathrm{C}$, (e) $150{ }^{\circ} \mathrm{C}$, (f) $160{ }^{\circ} \mathrm{C}$. 
進行しないと考えられる。 これに対して, $130{ }^{\circ} \mathrm{C}$ 以上では, PTMPSの結晶が解け始めることでフェニル基の束縛が解 放されるとともにすべり運動が顕著化し，ロール延伸によ る応力印加が有効に作用した結果，分子鎖が高度に配向し たものと考えられる.

以上， $140{ }^{\circ} \mathrm{C}$ でロール延伸したフィルムには，伸び切り 鎖結晶が含まれていることが明らかとなった。このフィル ムの DSC 測定を行ったところ，未延伸フィルムと同じ 130 ${ }^{\circ} \mathrm{C}$ 付近の融解ピークの他に, $160{ }^{\circ} \mathrm{C} に も$ 融解ピークが現れ ていた（図11（b))。このロール延伸フィルムの昇温過程 におけるin-situ X線計測を行ったところ，この高温側ピ ークは伸び切り鎖結晶の融解に起因することが明らかとな った. したがって，ロール延伸フィルムは高い物性を有し ていることが示唆される。そこで，未延伸フィルムと物性 を比較するために，引張り試験を室温にて行なった（図 12 (a)). 応力・ひずみ曲線の初期勾配から引張り弾性率 を，また，破断時の最大応力から破断強度を算出したとこ ろ，それぞれ，1.7 GPaおよび $20 \mathrm{MPa}$ が得られ，各種フ イルム材として利用可能な值であった。また，これらの值 は，未延伸フィルムの約 2 倍および 4 倍であり，特に，破 断強度の值が顕著に高くなっている.ささら，前述したよ うに，極めて透明であり（図12（b)），その高い分子配向 性を利用して偏光フィルム等への応用が期待される.
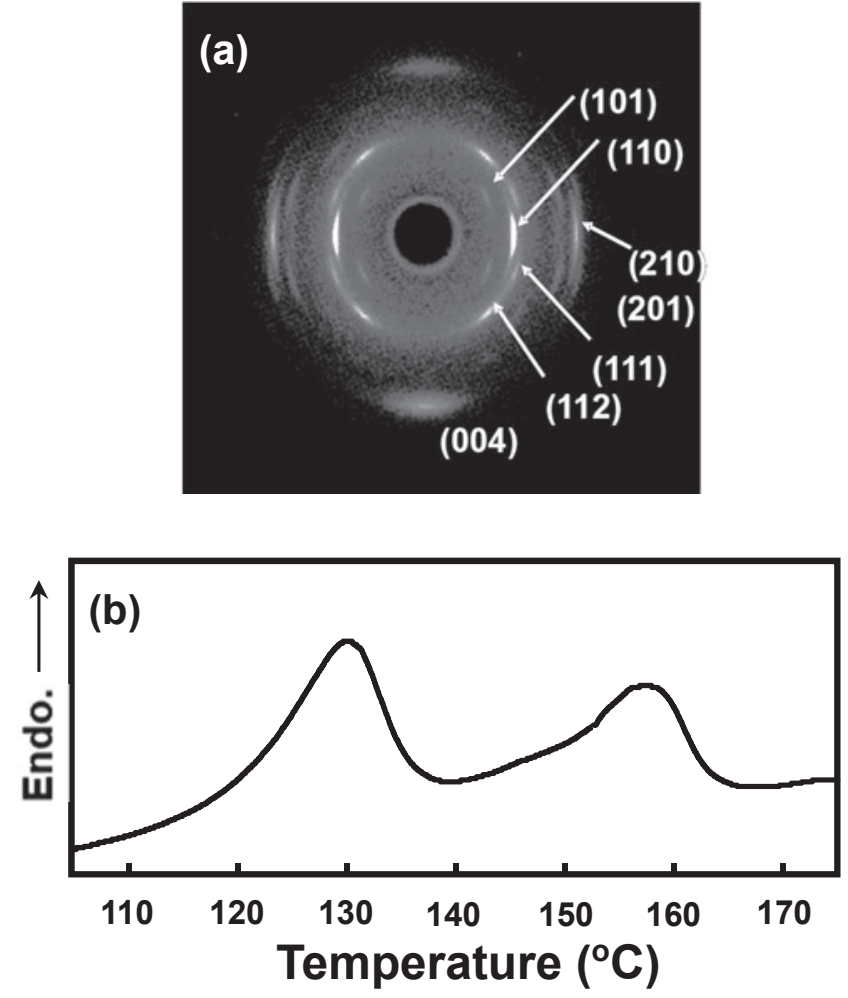

図11 $140{ }^{\circ} \mathrm{C}$ でロール延伸したPTMPS フィルムのWAXD像におけ る各反射の指数付け（a）と昇温速度 $10{ }^{\circ} \mathrm{C} / \mathrm{min}$ で得られた DSC 融解曲線 (b).
5. PTMPSとシリコーン・エラストマーのブレンド ${ }^{13)}$

このような結晶性 PTMPS と架橋前の反応性シリコーン を両成分を溶解可能な 1,2-ジクロロベンゼン (DCB) 中で ブレンド後, 架橋を進行させることで, 高強度かつ高伸度 を兼ね備えたシリコーン・エラストマーの創製を試みた。 PTMPSを約 5\%の濃度で溶かしたDCB溶液を調製した。 所定量のこの溶液に，反応性シリコーン原料として，末端 にビニル基を持つPDMSと末端と側鎖にビニル基を持つ ビニルメチルシロキサンージメチルシロキサンコポリマー （VDV）およびHBCを加え，これを $200{ }^{\circ} \mathrm{C} に$ 昇温するこ とで溶媒の除去と架橋反応を同時進行させた。 この時, PTMPSの比率が 1 〜 $50 \mathrm{wt} \%$ となるフィルムを作製した.

PTMPSなしのフィルムは透明であったが, PTMPSの 比率が多くなるにつれて白濁した。 また, PTMPS比率が $10 \mathrm{wt} \%$ を超えると白濁した部分と透明な部分が巨視的に 分離してしまったが，30 wt\%以上では，均一なフィルム 形態を示していた。そこで，PTMPS比率が $0 ， 1 ， 3 ， 30$, $50 \mathrm{wt} \%$ のイルムについて, 応力・ひずみ曲線を比較し た（図13）。得られた曲線の傾きから算出した引張り弾性 率を図 14 に示した。 $1 ， 3 \mathrm{wt} \%$ 含有フィルムはPTMPSを
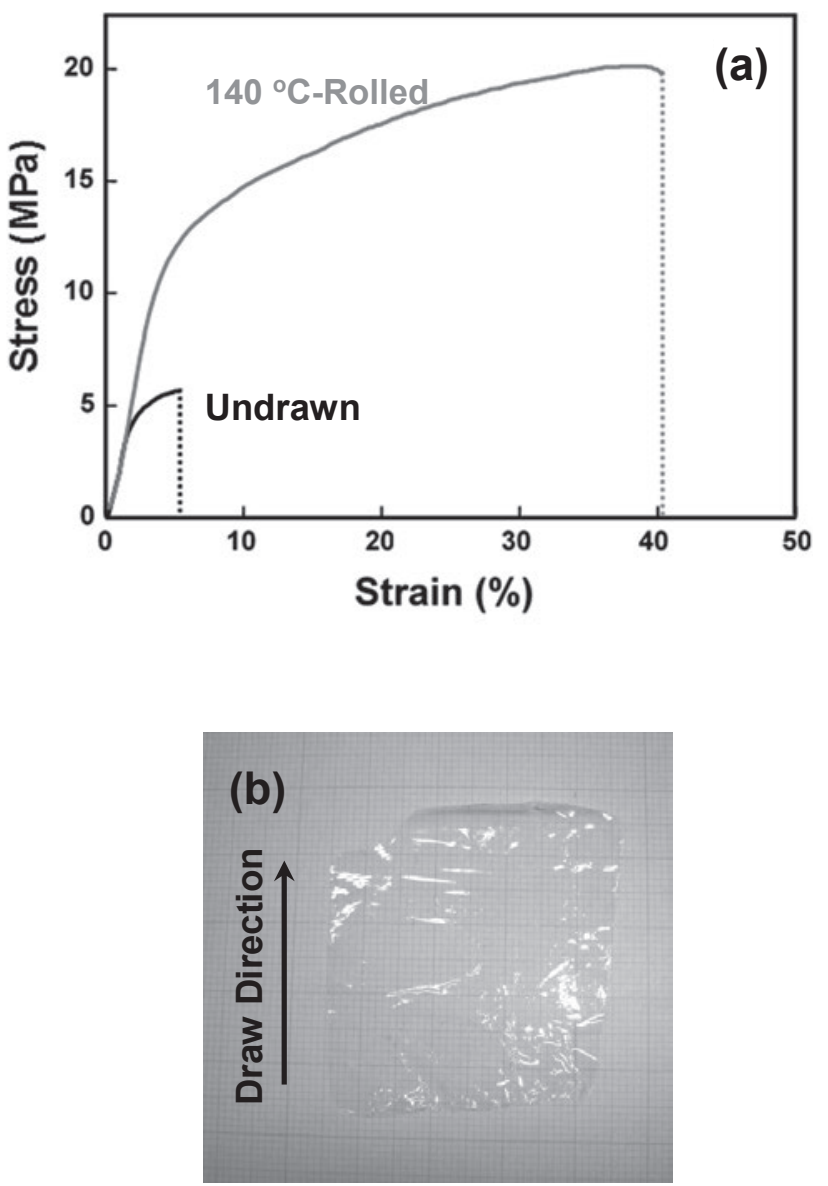

図 $12140{ }^{\circ} \mathrm{C}$ でロール延伸したPTMPSフィルムの引張り試験結果 （a）と実物写真（b)。引張り試験は，未延伸フィルムと比較 した，写真に扔ける延伸方向は縦方向. 
含まないフィルムとほぼ同じ弾性率を示している。一方， 30, 50 wt\%含有フィルムは高い弾性率を示したが，高ひ ずみ領域では曲線の傾きが数分の 1 に減少する 2 段階の応 力・ひずみ挙動を示した。 これにより，応力・ひずみ曲線 の面積が非常に大きくなっていた．この面積值は，材料の 耐久性の指標となるので，各フィルムについて比較を行っ た（図 15）。これを見ると，1，3 wt\%含有フィルムに比 ベ，30，50 wt\%含有フィルムでは，100倍以上の高い值 を示していることがわかる.

これらの異なるPTMPS 比率で作製したフィルムの構造 を解析するために，SEM観察を行った。 $30 \mathrm{wt} \%$ 含有フィ ルムについて, PTMPSをクロロホルムに浸漬して抽出除 去し，エラストマー相のみとしたところ，球状の形態が集 合している様子が観察できた（図 16）。したがって， PTMPS相は，球状のエラストマー相の隙間を埋めるよう に充填され，PTMPS相が連続相として存在すると考えら

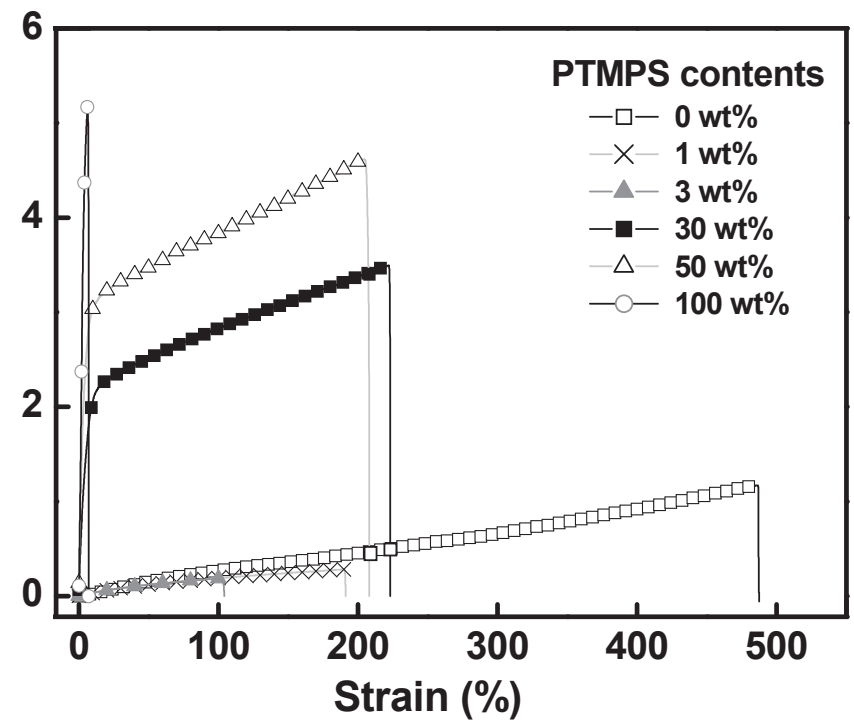

図13 異なるPTMPS比率で調製したブレンドフィルムの引張り試 験結果 (室温で測定).

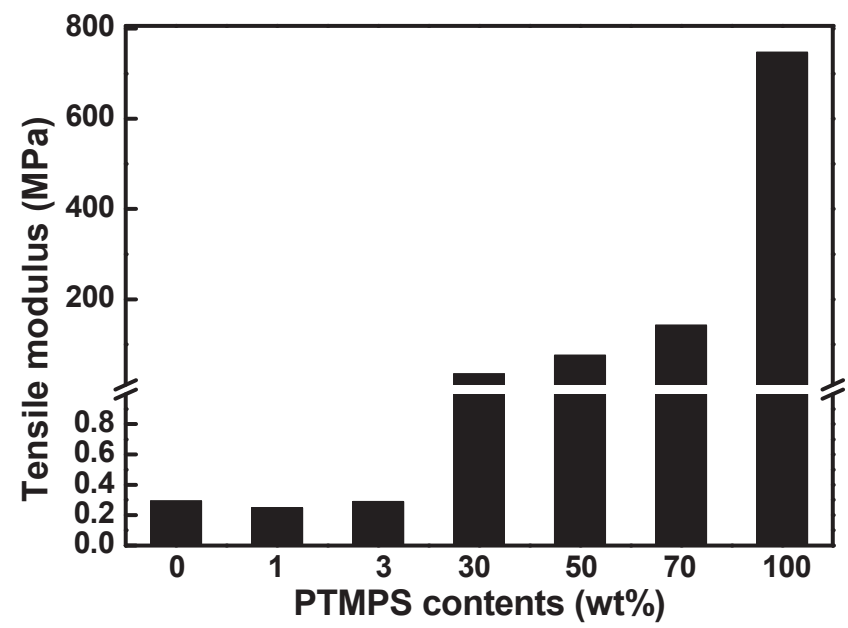

図14 異なるPTMPS比率で調製したブレンドフィルムの引張り弾 性率の比較.
れる. 2 段階の応力・ひずみ挙動を示す理由は, このよう な相分離構造に起因すると考えられる，すなわち，連続相 であるPTMPS相が低ひずみ領域で破壊されるのに対し て，高ひずみ領域では，球状の柔らかいエラストマー相が 変形するため, 応力・ひずみ曲線の傾きが減少すると考え られる。これらのことから，PTMPS 30 および50 wt\%ブ レンドフィルムは耐衝撃材料としての利用も期待できると 考えられる.

$$
\text { 6. お わ り に }
$$

本稿では, 構造制御の側面から，シリコーン樹脂の高性 能化について検討した事例を紹介した。フェニレン基のシ リコーン主鎖への導入や多分岐型架橋剂など，分子構造制 御による高性能化とともに，結晶性成分の導入や延伸によ る配向処理といった高次構造制御による高性能化を組み合 わせることで, 従来の炭化水素系エラストマーとは違った 応用展開が図れると期待される。

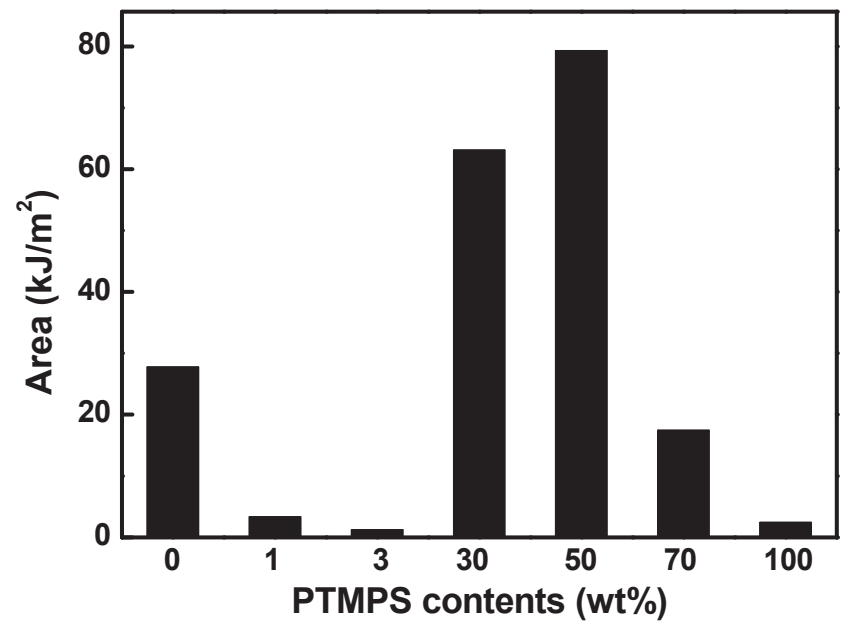

図15引張り試験時の応力・ひずみ曲線の面積.

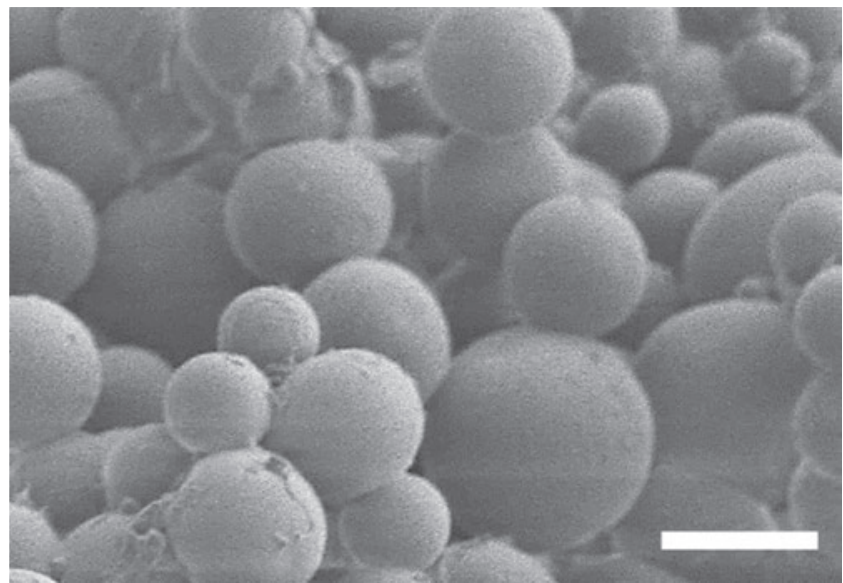

図 16 PTMPS30 wt\%含有フィルムをクロロホルム抽出して得られ たSEM像．スケールバーは $1 \mu \mathrm{m}$. 


\section{謝辞}

本研究の一部は, 中谷電子計測技術振興財団・開発研究 助成金により行われました。深く謝意を表します。なお， 本研究におけるSAXS 測定は, SPring-8放射光を用いて行 われた（2008A1148, 2008B1989, 2009B1780, 2015B1069）.

\section{References}

1 ) Uehara, H.; Saitoh, M.; Morita, R.; Akiyama, E.; Yamanobe, T.: Macromolecules, 47, 888 (2014)

2 ) Merker, R. L.; M. J. Scott, J. Polym. Sci., Pt. A, 2, 15 (1964)

3 ) Uehara, H.; Obana, T.; Kakiage, M.; Akiyama, E.; Yamanobe, T. Macromolecules, 45, 7446 (2012)

4 ) Uehara, H.; Obana, T.; Kakiage, M.; Tanaka, H.; Masunaga, H.; Yamanobe, T.; Akiyama, E.: J. Mater. Chem. C, 2, 373 (2014)

5 ) Uehara, H.; T. Yamanobe, T.; Akiyama, E.: Plastics, 65, 34 (2014)

6 ) Yao, Y.; Lu, G.-Q.; Boroyevich, D.; Ngo, K. D. T.: Polymer, 55, $4232(2014)$

7 ) Dewimille, L.; Bresson, B.; Bokobza, L.: Polymer, 46, 4135 (2005)

8 ) Clément, F.; Lapra, A.; Bokobza, L.; Monnerie, L.; Ménez, P.: Polymer, 42, 6259 (2001)

9 ) Paul, R.; Mark, J. E.: Prog. Polym. Sci., 35, 893 (2010)

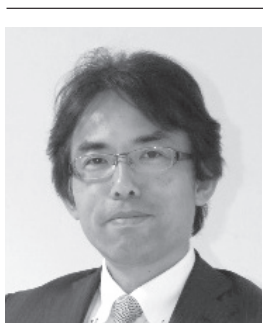

上原 宏樹; 群馬大学大学院理工学府分子科 学部門（３76-8515群馬県桐生市天神町 1-5-1) 教授. 博士 (理学). 平成 9 年, 東京理科大学 大学院理学研究科化学専攻博士課程修了. 同 年, 群馬大学工学部材料工学科・助手, 平成 19 年, 大学院工学研究科・准教授, 平成 28 年, 大学院理工学府・教授，現在に至る。専門は， 高分子固体物性, 高分子構造. 高分子学会関 東支部常任幹事, 繊維学会関東支部委員.

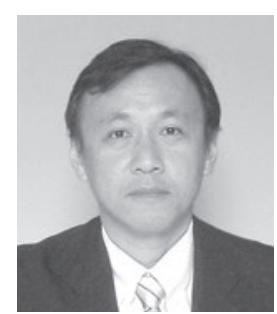

山延 健 ; 群馬大学大学院理工学府分子科学 部門（干 376-8515群馬県桐生市天神町1-5-1） 教授. 工学博士. 昭和 61 年, 東京工業大学理 工学研究科高分子工学専攻博士課程修了. 昭 和 61 年, 東京工芸大学工学部・助手. 平成 5 年, 群馬大学工学部・助教授. 平成 19 年, 群 馬大学大学院工学研究科・教授．専門は，高 分子構造. 複合材料懇話会会長
10) Yang, D.; Zhang, W.; Jiang, B.; Guo, Y.: Compos. Pt. A-Appl. S., 44, 70 (2013)

11) Pan, Y.; Wang, M. Z.; Xiao, H.: Compos. Sci. Technol., 77, 81 (2013)

12) Wang, L.; Liu, Q.; Jing, D.; Zhou, S.; Shao, L.: J. Dent., 42, 475 (2014)

13) Isogai, Y.; Morita, R.; Uehara, H.; Yamanobe, T.; Akiyama, E.: Kobunshi Ronbunshu, 72, 110 (2015)

14) Uehara, H.; Yamanobe, T.; Komoto, T.: Macromolecules, 33, 4861 (2000)

15) Kakiage, M.; Sekiya, M.; Yamanobe, T.; Komoto, T.; Sasaki, S.; Murakami, S.; Uehara, H.: J. Phys. Chem. B, 112, 5311 (2008)

16) Kojima, M.; Magill, J. H.: J. Polym. Sci., 12, 317 (1974)

17) Gardner, K. H.; Magill, J. H.; Atkins, E. D. T.: Polymer, 19, 370 (1978)

18) Kakiage, M.; Sekiya, M.; Yamanobe, T.; Komoto, T.; Sasaki, S.; Murakami, S.; Uehara, H.: Polymer, 48, 7385 (2007)

\section{日本語表記参考文献}

5 ）上原宏樹, 山延健, 秋山映一：プラスチックス，65，34（2014）

13）磯貝由紀子, 森田涼介, 上原宏樹, 山延健, 秋山映一：高分子 論文集，72，110（2015）

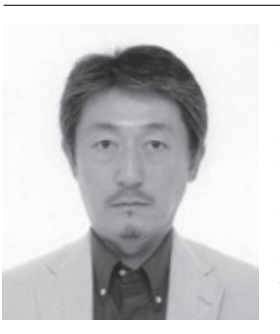

秋山 映一; (公財) 相模中央化学研究所高分子化 学グループ (广252-1193神奈川県綾瀨市早川27431)グループリーダー・主席研究員. 博士 (理学). 平成 4 年, 東京理科大学大学院理学研究科化学専攻 修士課程修了。同年(財)相模中央化学研究所・研究員 補, 平成 12 年, (株萑原総合研究所化学研究室・研 究員平成 17 年 (公財) 相模中央化学研究所高分 子化学グループ。公ループリーダー・主任研究分 平成29年主席研究員現在に至万專門は高 分子化学, 有機ケイ素化学. 高分子学会関東支部常 任幹事. 